Available online at GSC Online Press Directory

GSC Biological and Pharmaceutical Sciences

e-ISSN: 2581-3250, CODEN (USA): GBPSC2

Journal homepage: https://www.gsconlinepress.com/journals/gscbps

(RESEARCH ARTICLE)

\title{
Synthesis and antimicrobial screening of some Schiff bases
}

\author{
Baluja Shipra ${ }^{1, *}$, Chanda Sumitra ${ }^{2}$, Ganguly Sushmita ${ }^{3}$, Oza Swati ${ }^{1}$ and Nandha Kajal ${ }^{1}$ \\ ${ }^{1}$ Department of Chemistry, Saurashtra University, Rajkot, Gujarat, India. \\ 2 Department of Biosciences, Saurashtra University, Rajkot, Gujarat, India. \\ ${ }^{3}$ Department of Chemistry, Christ College, Rajkot, Gujarat, India.
}

Publication history: Received on 06 December 2019; revised on 18 December 2019; accepted on 19 December 2019

Article DOI: https://doi.org/10.30574/gscbps.2019.9.3.0232

\begin{abstract}
Some new Schiff bases were synthesized from pyrazolo aldehydes and triazoles and their structures were confirmed by IR, ${ }^{1} \mathrm{H}$ NMR, and Mass spectral data. All these synthesized compounds were tested in vitro for their antimicrobial potential in $\mathrm{N}, \mathrm{N}$-dimethyl formamide and dimethyl sulfoxide by agar well diffusion method. The antimicrobial strains were of Gram positive bacteria, Gram negative bacterial and fungal strains.
\end{abstract}

Keywords: Schiff bases; Triazole; Antimicrobial activity; Agar-well diffusion method; N N-dimethyl formamide

\section{Introduction}

Schiff bases are known to be versatile heterocyclic compounds which are intermediates of the preparation of various drugs, dyes and many other compounds [1,2]. Schiff bases are also known as azomethines. Schiff bases are used as intermediate for the preparation of azetidinone [3], formazone [4], thiazolidinone [5], arylacetamide, metal complexes $[6,7]$. Due to the multi applicability of this class of compounds, a lot of work has been done on Schiff bases $[8,9]$.

Further, Schiff bases possess a wide range of biological activities such as antimicrobial [10], antifungal [11, 12], antibacterial [13, 14], antitumor [15], anticancer [16], anti HIV [17, 18], anti-inflammatory [19], diuretic [20], antiparasitic [21] etc.

Due to these biological properties of Schiff bases, in the present work, some new Schiff bases are synthesized and their characterization was done by IR, NMR and mass spectral data. The screening of antimicrobial activity of these synthesized compounds was done in vitro against some Gram positive and Gram negative strains of bacteria as well as fungal strains in $\mathrm{N}, \mathrm{N}$-dimethyl formamamide (DMF) and dimethylsulfoxide (DMSO).

\section{Experimental}

\subsection{Synthesis of 4-amino-5-(pyridin-4-yl)-4H-1,2,4-triazole-3-thiol (Int-I)}

A methanolic solution of Isoniazide $(0.01 \mathrm{~mol})$ and $\mathrm{KOH}(0.012 \mathrm{~mol})$ was stirred for $1 \mathrm{hr}$. To this reaction mixture, 0.012 mol of carbon disulphide $\left(\mathrm{CS}_{2}\right)$ was added drop wise and the resulting solution was again stirred for 16 hrs at room temperature. The resulting solid was filtered, washed with diethyl ether and dried under vacuum to give solid product.

0.01 mol of this crude product and 0.01 mol of hydrazine hydrate were dissolved in minimum amount of water and the solution was refluxed for 2 hrs. The progress of the reaction was confirmed by TLC using hexane and ethyl acetate

\footnotetext{
${ }^{*}$ Corresponding author

E-mail address: shipra_baluja@rediffmail.com
}

Copyright (C) 2019 Author(s) retain the copyright of this article. This article is published under the terms of the Creative Commons Attribution Liscense 4.0 
mixture $(0.5: 0.5)$ as mobile phase. After completion of the reaction, the reaction mixture was poured into crushed ice. The resulting solid was filtered and dried under vacuum.

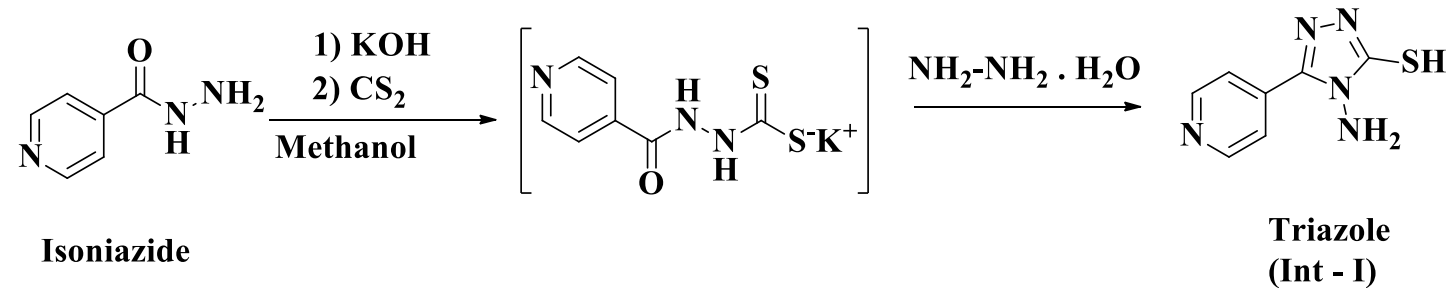

\subsection{Synthesis of 1, 3-diphenyl-1H-pyrazole-4-carbaldehyde (Int-II)}

To a methanolic solution of acetophenone $(0.01 \mathrm{M})$ and phenyl hydrazine $(0.01 \mathrm{M})$, catalytic amount of conentrated $\mathrm{HCl}$ was added and the solution was stirred at room temperature for about 10-15 minutes. The resulting solid was filtered, washed with cold methanol and crystallized. The product formed is (E)-2-phenyl-1-(1-phenylethylidene) hydrazine.

The above synthesized product (E)-2-phenyl-1-(1-phenyl ethylidene) hydrazine was added in a mixture of VilsmeierHaack reagent (prepared by drop wise addition of $3 \mathrm{ml} \mathrm{POCl} 3$ in ice cooled $15 \mathrm{ml}$ DMF (for 0.01 mol)) and the solution was refluxed for $1 \mathrm{hr}$. The completion of reaction was confirmed by analytical thin layer chromatography (TLC). The reaction mixture was poured into crushed ice and was kept for 12-14 hrs. The resulting product was filtered, washed and dried.
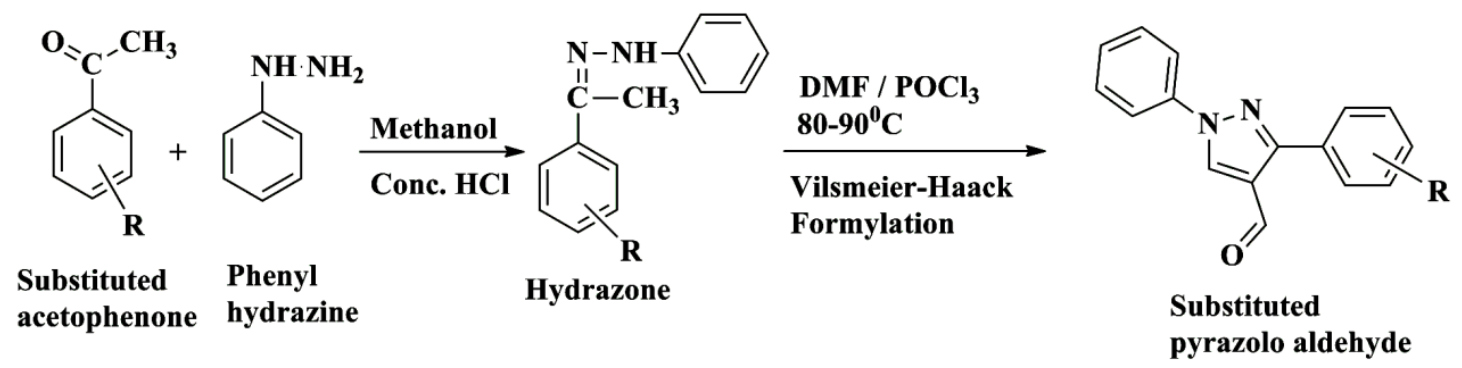

\subsection{Synthesis of Schiff bases}

The above synthesized triazole (Int-I) and substituted pyrazoloaldehyses (Int-II) were refluxed in isopropyl alcohol (IPA) in presence of catalytic amount of concentrated $\mathrm{HCl}$ at $85-90^{\circ} \mathrm{C}$ for $36-42 \mathrm{hrs}$. The reaction was monitored by TLC using using hexane and ethyl acetate mixture $(0.4: 0.6)$ as mobile phase. The completion of reaction was confirmed by Thin Layer Chromatography TLC (Performed on aluminum coated TLC plates gel- $\mathrm{G}_{60} \mathrm{~F}_{254}$ and accomplished on 0.5-mm (E. Merck)). Visualization of spot was made with UV light (254 and $365 \mathrm{~nm}$ ), an iodine vapor and other visualizing reagent. The reaction mixture was allowed to cool and the resulting solid was filtered, washed with methanol in order to remove polar impurities. The unreacted triazole (Int-I) was removed by washing the solid product with dilute HCl solution.
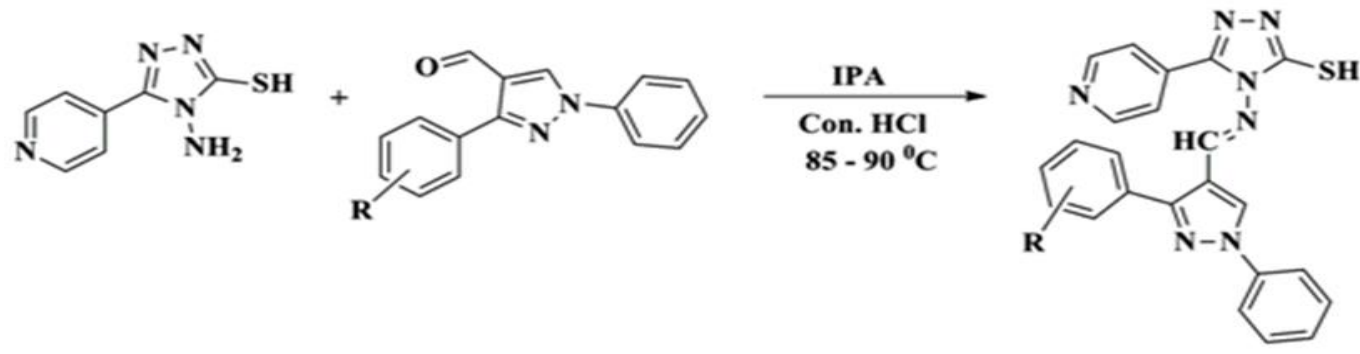

\subsection{Characterization of synthesized compounds}

The structures of all the synthesized compounds were confirmed by IR, $1 \mathrm{H}$ NMR and mass spectral data. IR spectra were recorded on IR affinity $1 \mathrm{~S}$ (furrier transport infra-red spectroscopy). 1H NMR spectra were taken on a Bruker AVANCE II 400. In all the cases, $1 \mathrm{H}$ NMR spectra were obtained in DMSO-d6 using TMS as an internal standard. The NMR signals 
are reported in $\delta$ ppm. Mass spectra were determined using direct inlet probe on a GCMS-QP-2010 mass spectrometer. Figures 1, 2 and3 show IR, 1H NMR and Mass spectra of compound ITA-1 respectively.

\subsection{Microorganisms tested}

The studied microorganisms were obtained from National Chemical Laboratory (NCL), Pune, India. The microorganisms were maintained at $4^{\circ} \mathrm{C}$. The Gram positive bacteria studied were Staphylococcus aureus ATCC29737 (SA), Corynebacterium rubrum ATCC14898 (CR), Listeria monocytogenes ATCC19112 (LM), Bacillus cereus ATCC11778 (BC); Gram negative bacteria were Pseudomonas aeruginosa ATCC27853(PA), Escherichia coli NCIM2931 (EC), Klebsiell apneumoniae NCIM2719 (KP), Salmonella typhimurium ATCC23564 (ST) and Fungi were Candida albicans ATCC2091 (CA), Cryptococcus neoformans NCIM3542 (CN), Candida glabrata NCIM3448 (CG), Candida epicola NCIM3367 (CE). The organisms were maintained on nutrient agar and MGYP medium (Hi Media, India) for bacteria and fungi respectively, at $4^{\circ} \mathrm{C}$ and sub-cultured before use. The microorganisms studied are clinically important ones causing several infections and food spoilage. The selected Gram positive and Gram negative bacteria are common pathogenic bacteria and their study are clinically important causing several infections, food borne diseases, spoilages, skin infection and it is essential to overcome them through some active therapeutic agents. Both Gram positive and Gram negative were selected to study broad spectrum of activity of synthesized compounds.

\subsection{Preparation of solutions of compounds}

For all the compounds, DMF and DMSO were used for screening of antimicrobial activity. The solution of $20 \mathrm{mg} / \mathrm{ml}$ concentration was prepared for all the compounds.

\subsection{Agar well diffusion method}

In vitro, antimicrobial activity of the different Schiff bases was studied against pathogenic microbial strains by the Agar well diffusion method [22]. Mueller Hinton No. 2 / Sabouraud dextrose agar (Hi-media) was used for the antibacterial and antifungal susceptibility test respectively. The Mueller Hinton agar and Sabouraud dextrose agar was melted and cooled to $48-50^{\circ} \mathrm{C}$ and a standardized inoculum $(1.5 \times 108 \mathrm{CFU} / \mathrm{ml}, 0.5 \mathrm{McFarland})$ was then added aseptically to the molten agar and poured into sterile Petri dishes; wells $(8.5 \mathrm{~mm})$ were prepared in the seeded agar plates. The test compound $(100 \mu \mathrm{l})$ was introduced into the well. The plates were incubated overnight at $37^{\circ} \mathrm{C}$ and $28^{\circ} \mathrm{C}$ for $24 \mathrm{~h}$ and 48 $\mathrm{h}$ respectively, for bacteria and fungi. The microbial growth was determined by measuring the diameter of the zone of inhibition and the mean values are considered.

\section{Results and discussion}

In total 10 compounds were synthesized (ITA-1 to ITA-10). The physical constants of all the synthesized compounds are given in Table 1.The IR, NMR, Mass spectral data confirmed their molecular structure.

Table 1 Physical constants of the synthesized compounds (ITA-1 to ITA-10).

\begin{tabular}{lllllll}
\hline $\begin{array}{l}\text { Compound } \\
\text { Code }\end{array}$ & $\begin{array}{l}\text { Substitution } \\
\text { R }\end{array}$ & $\begin{array}{l}\text { Molecular } \\
\text { formula }\end{array}$ & $\begin{array}{l}\text { Molecular } \\
\text { Weight } \\
\text { g/mol }\end{array}$ & $\begin{array}{l}\text { Yield } \\
\text { (\%) }\end{array}$ & $\begin{array}{l}\text { Rf } \\
\text { value }\end{array}$ & $\begin{array}{l}\text { Melting } \\
\text { point } \\
\text { oC }\end{array}$ \\
\hline ITA-1 & $-4-\mathrm{Cl}$ & $\mathrm{C}_{23} \mathrm{H}_{16} \mathrm{ClN}_{7} \mathrm{~S}$ & 457.09 & 85 & 0.59 & 210 \\
ITA-2 & $-2-\mathrm{OH}$ & $\mathrm{C}_{23} \mathrm{H}_{17} \mathrm{ClN}_{7} \mathrm{OS}$ & 439.49 & 74 & 0.51 & 224 \\
ITA-3 & $-4-\mathrm{F}$ & $\mathrm{C}_{23} \mathrm{H}_{16} \mathrm{FN}_{7} \mathrm{~S}$ & 441.48 & 81 & 0.53 & 291 \\
ITA-4 & $-3-\mathrm{NO}_{2}$ & $\mathrm{C}_{23} \mathrm{H}_{16} \mathrm{~N}_{8} \mathrm{O}_{2} \mathrm{~S}$ & 468.49 & 76 & 0.56 & 211 \\
ITA-5 & $-4-\mathrm{Br}$ & $\mathrm{C}_{23} \mathrm{H}_{16} \mathrm{BrN}_{7} \mathrm{~S}$ & 502.39 & 87 & 0.56 & 281 \\
ITA-6 & $-4-\mathrm{OCH} 3$ & $\mathrm{C}_{24} \mathrm{H}_{19} \mathrm{~N}_{7} \mathrm{OS}$ & 453.52 & 83 & 0.58 & 288 \\
ITA-7 & $-4-\mathrm{CH}_{3}$ & $\mathrm{C}_{24} \mathrm{H}_{19} \mathrm{~N}_{7} \mathrm{~S}$ & 437.52 & 80 & 0.61 & 301 \\
ITA-8 & $-3,4-\mathrm{diOCH} \mathrm{CH}_{3}$ & $\mathrm{C}_{25} \mathrm{H}_{21} \mathrm{~N}_{7} \mathrm{O}_{2} \mathrm{~S}$ & 483.54 & 85 & 0.50 & 284 \\
ITA-9 & $-4-\mathrm{OH}$ & $\mathrm{C}_{23} \mathrm{H}_{17} \mathrm{~N}_{7} \mathrm{OS}$ & 439.49 & 77 & 0.51 & 298 \\
ITA-10 & $-4-\mathrm{NO}_{2}$ & $\mathrm{C}_{23} \mathrm{H}_{16} \mathrm{~N}_{8} \mathrm{O}_{2} \mathrm{~S}$ & 468.49 & 81 & 0.53 & 219 \\
\hline
\end{tabular}




\subsection{Spectral Data}

\subsubsection{ITA-1: $\operatorname{IR}\left(\mathrm{cm}^{-1}\right)$}

3614.60 (-NH, Str.), 3068.75 (Ar-H Str.), 1593.20 (-NH Bending), 1242-1010 (-CH in plane bending, phenyl ring), 692.44 (-CH str. 5-adjecent c atoms), 2610.12 (-SH Str.), 1635.64 (-NH, Bending (Sec.), 765.74 (C-Cl Str.), ${ }^{1}$ H NMR (DMSO-d $)$ $\boldsymbol{\delta}(\boldsymbol{p p m})$ : $7.436-7.615$ (5H, multiplet, $-\mathrm{CH}), 7.871-7.892$ (2H, doublet, $-\mathrm{CH}), 8.051-8.071(2 \mathrm{H}$, doublet, $-\mathrm{CH}), 8.210-$ 8.226 (2H, doublet, $-\mathrm{CH}), 8.887-8.903$ (2H, doublet, $-\mathrm{CH}), 9.398$ (1H, singlet, $-\mathrm{CH}), 9.714$ (1H, singlet, $-\mathrm{CH}), 14.719$ (1H, singlet, $-\mathrm{SH}) \mathbf{M S}:(\mathrm{m} / \mathrm{z})=457$.

\subsubsection{ITA-2: $\operatorname{IR}\left(\mathrm{cm}^{-1}\right)$}

3710.25 (-OH Str. (free -OH),3645.42 (-NH, Str.), 3057.67 (Ar-H Str.), 2690.14 (-SH Str.), 1608.63 (-NH, Bending (Sec.), 1583.56 (-NH Bending), 1242-1010 (-CH in plane bending, phenyl ring), 1066.64 (-OH bending), 682.80 (-CH str. 5adjecent c atoms), ${ }^{1} \boldsymbol{H}$.

\subsection{3. $N M R\left(D M S O-d_{6}\right) \delta(p p m)$}

6.942 - 7.418 (5H, multiplet, -CH), 7.433 - 7.572 (2H, doublet, $-\mathrm{CH}), 7.861$ (2H, singlet, $-\mathrm{CH}), 8.010$ - 8.028 (2H, doublet, $-\mathrm{CH}), 8.740$ (2H, singlet, $-\mathrm{CH}), 9.295$ (1H, singlet, $-\mathrm{OH}), 9.472$ (1H, singlet, $-\mathrm{CH}), 9.829$ (1H, singlet, $-\mathrm{CH}), 14.419(1 \mathrm{H}$, singlet, $-\mathrm{SH}) \mathbf{M S}:(\mathbf{m} / \mathbf{z})=439$.

\subsubsection{ITA-3: $\operatorname{IR}\left(\mathrm{cm}^{-1}\right)$}

3590.12 (-NH, Str.), 3012.81 (Ar-H Str.), 2674.18 (-SH Str.), 1747.51 (-NH, Bending (Sec.), 1541.12 (-NH Bending), $1242-$ 1010 (-CH in plane bending, phenyl ring), 1008.77 (C-F Str.)) 682.80 (-CH str. 5-adjecent c atoms), ${ }^{1} \boldsymbol{H}$ NMR (DMSO-d 6$)$ $\boldsymbol{\delta}(\boldsymbol{p p m})$ : 7.067 - 7.611 (5H, multiplet, $-\mathrm{CH}), 7.789-7.811$ (2H, doublet, $-\mathrm{CH}), 8.050-8.069$ (2H ,doublet, -CH), $8.346-$ $8.360(2 \mathrm{H}$, doublet, $-\mathrm{CH}), 8.958-9.008(2 \mathrm{H}$, singlet, $-\mathrm{CH}), 9.361(1 \mathrm{H}$, singlet, $-\mathrm{CH}), 9.679(1 \mathrm{H}$, singlet, $-\mathrm{CH}), 14.772(1 \mathrm{H}$, singlet, $-\mathrm{SH}), \mathbf{M S}:(\mathrm{m} / \mathrm{z})=441$.

\subsubsection{ITA-4: $\operatorname{IR}\left(\mathrm{cm}^{-1}\right)$}

3517.27 (-NH, Str.), 2970.38 (Ar-H Str.), 2710.12 (-SH Str.), 1740.27 (-NH, Bending (Sec.), 1531.48 (-NH Bending), $1242-$ 1010 (-CH in plane bending, phenyl ring), 1346.31 (-NO ${ }_{2}$ Str. (aromatic), 682.78 (-CH str. 5-adjecent c atoms), ${ }^{1} \boldsymbol{H} \mathbf{N M R}$ (DMSO-d $)^{\delta} \boldsymbol{\delta}(\mathbf{p p m})$ : $7.454-7.631$ (5H, multiplet, -CH), 8.057 - 8.088 (2H, doublet, -CH), 8.308 (2H, singlet, -CH), 8.461 -8.512 (2H, doublet, $-\mathrm{CH}), 8.814$ (2H, singlet, $-\mathrm{CH}), 9.442$ (1H, singlet, $-\mathrm{CH}), 9.809$ (1H, singlet, $-\mathrm{CH}), 14.613(1 \mathrm{H}$, singlet, $-\mathrm{SH}), M S:(\mathrm{m} / \mathrm{z})=468$.

\subsection{6. $I T A-5: \operatorname{IR}\left(\mathrm{cm}^{-1}\right)$}

3545.38 (-NH, Str.), 2970.38 (Ar-H Str.), 2710.12 (S-H Str.), 1747.51 (-NH, Bending (Sec.), 1537.27 (-NH Bending), $1242-$ 1010 (-CH in plane bending, phenyl ring), 690.52 (-CH str. 5-adjecent c atoms), 612.57 (C-Br Str.), ${ }^{1} \boldsymbol{H}$ NMR (DMSO-d $)$ $\boldsymbol{\delta}(\boldsymbol{p p m}): 7.437-7.732$ (5H, multiplet, $-\mathrm{CH}), 7.799-7.820$ (2H, doublet, $-\mathrm{CH}), 8.051-8.071$ (2H, doublet, $-\mathrm{CH}), 8.329-$ 8.345 (2H, doublet, $-\mathrm{CH}), 8.941-8.957$ (2H, doublet, $-\mathrm{CH}), 9.406(1 \mathrm{H}$, singlet, $-\mathrm{CH}), 9.729(1 \mathrm{H}$, singlet, $-\mathrm{CH}), 14.796(1 \mathrm{H}$, singlet, $-\mathrm{SH}), \mathbf{M S}:(\mathrm{m} / \mathbf{z})=502$.

\subsubsection{ITA-6: $\operatorname{IR}\left(\mathrm{cm}^{-1}\right)$}

3631.17 (-NH, Str.), 2970.38 (Ar-H Str.), 2914.25 (-CH str., alkane), 2805.07 (-SH Str.), 1735.93 (-NH, Bending (Sec.), 1527.62 (-NH Bending), 1346.31 (-CH Ben. (alkane), (1242-1010 (-CH in plane bending, phenyl ring), 688.59 (-CH str. 5-adjecent c atoms), ${ }^{1} \boldsymbol{H}$ NMR (DMSO-d6) $\boldsymbol{\delta}(\mathbf{p p m}): 3.624$ (3H, singlet, -OCH3), $7.236-7.487$ (5H, multiplet, -CH), 7.581 - 7.622 (2H, doublet, -CH), $7.963-8.024$ (2H, doublet, $-\mathrm{CH}), 8.247-8.283$ (2H, doublet, -CH), $8.903-8.921$ (2H, doublet, 2H), 9.321 (1H, singlet, $-\mathrm{CH}), 9.784$ (1H, singlet, $-\mathrm{CH}), 14.689$ (1H, singlet, $-\mathrm{SH}), \boldsymbol{M S}:(\mathbf{m} / \mathbf{z})=453$.

\subsubsection{ITA-7: $\operatorname{IR}\left(\mathrm{cm}^{-1}\right)$}

3628.10 (-NH, Str.), 3030.17 (Ar-H Str.), 2937.59 (-CH str., alkane), 2687.45 (S-H Str.), 1735.93 (-NH, Bending (Sec.), 1537.27 (-NH Bending), 1330.88 (-CH Ben. (alkane), (1242-1010 (-CH in plane bending, phenyl ring), 675.09 (-CH str. 5-adjecent c atoms), ${ }^{1} \boldsymbol{H}$ NMR (DMSO-d $) \boldsymbol{\delta}(\boldsymbol{p p m}): 2.402$ (3H, singlet, - $\left.\mathrm{CH}_{3}\right), 7.324-7.613$ (5H, multiplet, -CH), $7.740-$ 7.760 (2H, doublet, -CH), $8.059-8.079$ (2H, doublet, $-\mathrm{CH}), 8.417-8.434$ (2H, doublet, $-\mathrm{CH}), 8.979-8.996$ (2H, doublet, $-\mathrm{CH}), 9.383$ (1H, singlet, $-\mathrm{CH}), 9.729$ (1H, singlet, $-\mathrm{CH}), 14.838$ (1H, singlet, $-\mathrm{SH}), \boldsymbol{M S}:(\mathbf{m} / \mathbf{z})=437$. 


\subsection{9. $I T A-8: \operatorname{IR}\left(\mathrm{cm}^{-1}\right)$}

3537.46 (-NH, Str.), 3003.17 (Ar-H Str.), 2939.52 (-CH str., alkane), 2835.36 (-SH Str.), 1735.93 (-NH, Bending (Sec.), 1525.69 (-NH Bending), 1352.10 (-CH Ben. (alkane), (1242-1010 (-CH in plane bending, phenyl ring), 682.80 (-CH str. 5-adjecent c atoms), ${ }^{1} \mathbf{H}$ NMR (DMSO-d 6 ) $\boldsymbol{\delta}$ (ppm) : 3.561 (3H, singlet, $\left.-\mathrm{OCH}_{3}\right), 4.254$ (3H, singlet, - $\left.\mathrm{OCH}_{3}\right), 6.845-7.325$ (5H, multiplet, $-\mathrm{CH}), 7.325-7.486(2 \mathrm{H}$, doublet, $-\mathrm{CH}), 7.963(2 \mathrm{H}$, singlet, $-\mathrm{CH}), 8.215-8.752$ (3H, multiplet, $-\mathrm{CH}), 9.347$ (1H, singlet, -CH), 9.876 (1H, singlet, $-\mathrm{CH}), 14.753$ (1H, singlet, $-\mathrm{SH}), \boldsymbol{M S}:(\boldsymbol{m} / \mathbf{z})=483$.

\subsubsection{ITA-9: $\operatorname{IR}\left(\mathrm{cm}^{-1}\right)$}

3727.34 (-OH Str. (free OH),3599.61 (-NH, Str.), 3064.89 (Ar-H Str.), 2851.09 (-SH Str.), 1635.64 (-NH, Bending (Sec.), 1585.49 (-NH Bending), 1242-1010 (-CH in plane bending, phenyl ring), 1055.06 (-OH bending), 690.52 (C-H str. 5adjecent c atoms), ${ }^{1} \boldsymbol{H}$ NMR (DMSO-d 6 ) $\boldsymbol{\delta}$ (ppm) : $7.254-7.423$ (5H, multiplet, -CH), $7.632-7.662$ (2H, doublet, -CH), $7.963-8.025(2 \mathrm{H}$, doublet, $-\mathrm{CH}), 8.325-8.348(2 \mathrm{H}$, doublet, $-\mathrm{CH}), 8.964-8.989(2 \mathrm{H}$, doublet, $-\mathrm{CH}), 9.023(1 \mathrm{H}$, singlet, $-\mathrm{OH}), 9.452(1 \mathrm{H}$, singlet, $-\mathrm{CH}), 9.996(1 \mathrm{H}$, singlet, $-\mathrm{CH}), 14.631(1 \mathrm{H}$, singlet, $-\mathrm{SH}), \boldsymbol{M S}:(\boldsymbol{m} / \mathbf{z})=439$.

\subsubsection{ITA-10: $\operatorname{IR}\left(\mathrm{cm}^{-1}\right)$}

3612.79 (-NH, Str.), 2970.38 (Ar-H Str.), 2708.06 (-SH Str.), 1735.93 (-NH, Bending (Sec.), 1583.56 (-NH Bending), 12421010 ( $-\mathrm{CH}$ in plane bending, phenyl ring), 1338.60 ( $-\mathrm{NO}_{2}$ Str. (aromatic), 678.94 (-CH str. 5 -adjecent c atoms), ${ }^{1} \boldsymbol{H} \mathbf{N M R}$ (DMSO-d6) $\boldsymbol{\delta}(\mathbf{p p m})$ : 6.968 - 7.453 (5H, multiplet, -CH), 7.632 - 7.745 (2H, doublet, -CH), 8.124 - 8.156 (2H, doublet, $\mathrm{CH}), 8.412-8.457$ (2H, doublet, - $\mathrm{CH}), 9.002-9.347$ (2H, doublet, $-\mathrm{CH}), 9.457$ (1H, singlet, -CH), 9.876 (1H, singlet, - $\mathrm{CH}$ ), $14.632(1 \mathrm{H}$, singlet, $-\mathrm{SH}), \boldsymbol{M S}:(\mathbf{m} / \mathbf{z})=468$.

\section{Antimicrobial activity}

Figure 4 [A] shows zone of inhibition against Gram positive bacteria in DMF. It is observed that except ITA-4 and ITA10 , all the compounds could inhibit BC and maximum inhibition is observed by ITA-5. Against SA, only three compounds ITA-2, ITA-3 and ITA- 5 showed inhibition. The maximum is observed by ITA-5 and minimum is by ITA-3. Only ITA-1, ITA-5 and ITA-7 could inhibit CR. However, LM is affected by only ITA-1. Other compounds had no effect on this bacterial strain. Thus, structure of compounds affects inhibition for different bacteria.

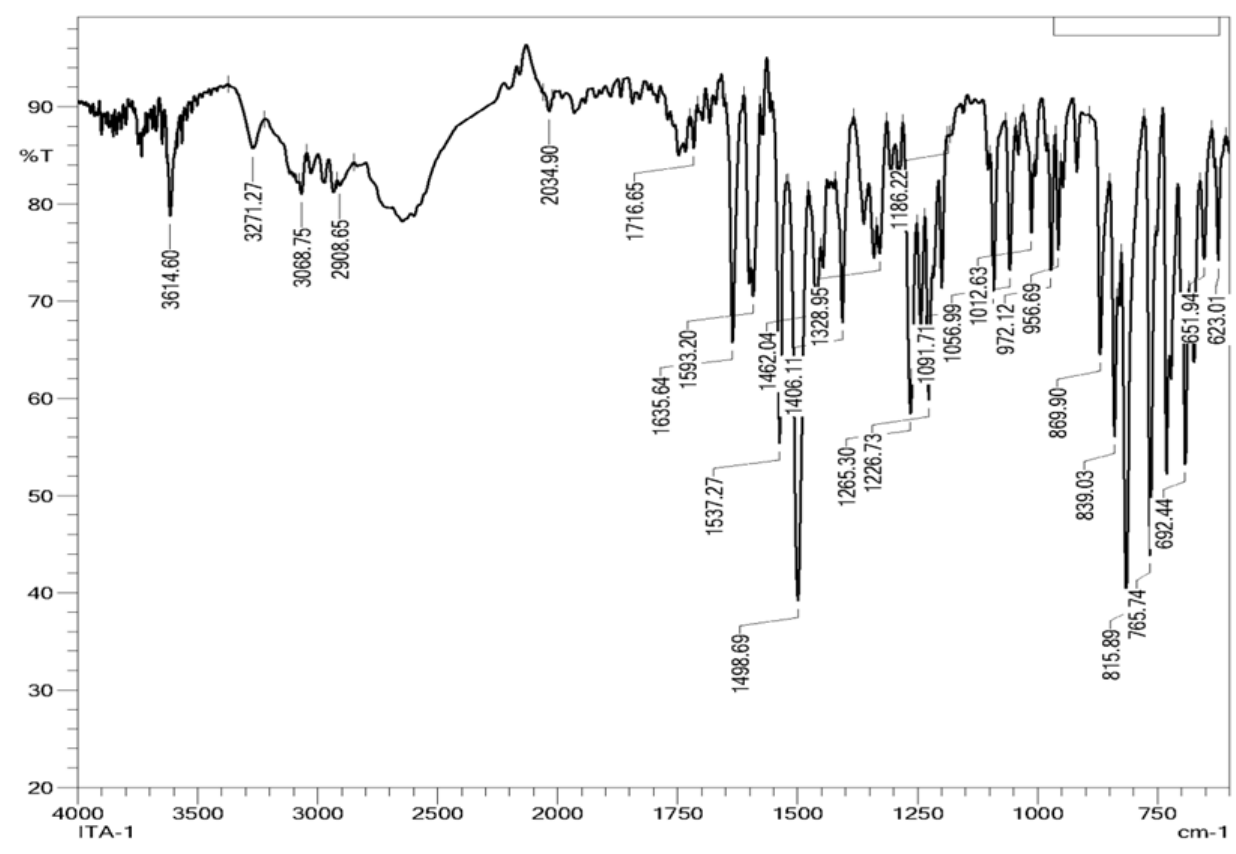

Figure 1 IR spectrum of compound ITA-1 


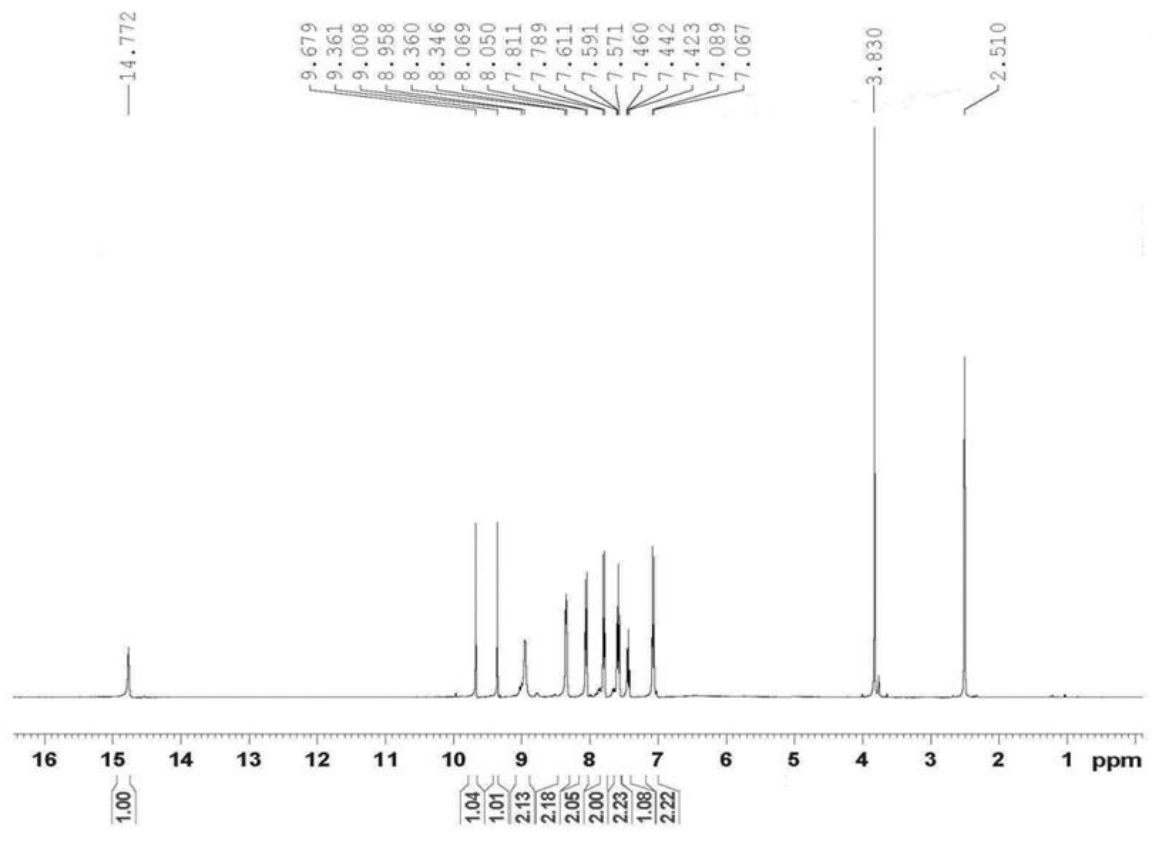

Figure $2{ }^{1} \mathrm{H}$ NMR spectrum of compound ITA-1.

As all the compounds have the same central moiety their substitutions are different which affect inhibition. Table 1 shows substitution groups of all the synthesized compounds. Thus, it is observed that compounds containing nitro groups (ITA-4 having 3- $\mathrm{NO}_{2}$ substitution and ITA-10 having 4- $\mathrm{NO}_{2}$ substitution) are not effective at all against $\mathrm{BC}$. Against SA, ITA-5 containing 4-bromo group is most effective which is followed by ITA-2 containing 2-hydroxy group. 4-flouro group (as in ITA-3) also inhibit SA to considerable extent. Other substitutions have no effect at all. The compound ITA-5 containing 4-bromo group exhibited maximum inhibition against CR whereas ITA-7 showed minimum inhibition which contains 4-methyl group. However, only ITA-1 containing 4-chloro group exhibited inhibition against LM. Thus, in DMF LM is the most resistant bacteria and BC is most susceptible bacteria.

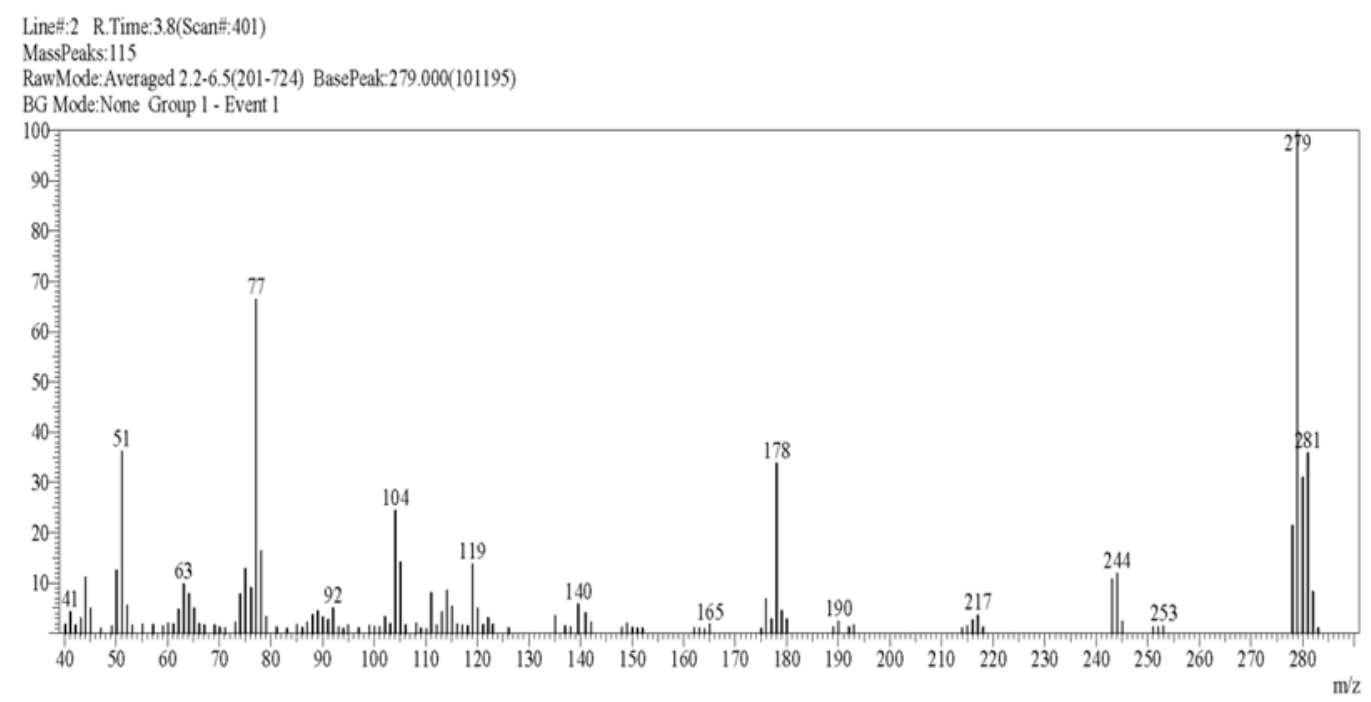

Figure 3 Mass spectrum of compound ITA-1.

Figure 4 [B] shows zone of inhibition against Gram positive bacteria in DMSO. Except ITA-3 and ITA-10 all the compounds could inhibit $\mathrm{BC}$ and maximum inhibition is observed by ITA-2 containing 2-hydroxy group. Thus, 4-fluoro and 4-nitro groups are not effective at all for BC, which are present in ITA-3 and ITA-10 respectively. Against SA, only few compounds exhibited inhibition and maximum is observed by ITA-9 containing 4-hydroxy group. ITA-3 containing 
4-fluoro had minimum inhibition against SA. ITA-1, ITA-2 and ITA-9 could inhibit CR and again ITA-2 having 2-OH group is most effective. This is followed by ITA-9 containing 4-hydroxy group. Thus, - $\mathrm{OH}$ group at either position is effective for CR. ITA-2, ITA-3, ITA-4 and ITA-9 showed moderate activity against LM and ITA-4 containing 3-nitro group is most effective. Thus, in DMSO, most of the compounds are effective against the selected Gram positive bacteria.
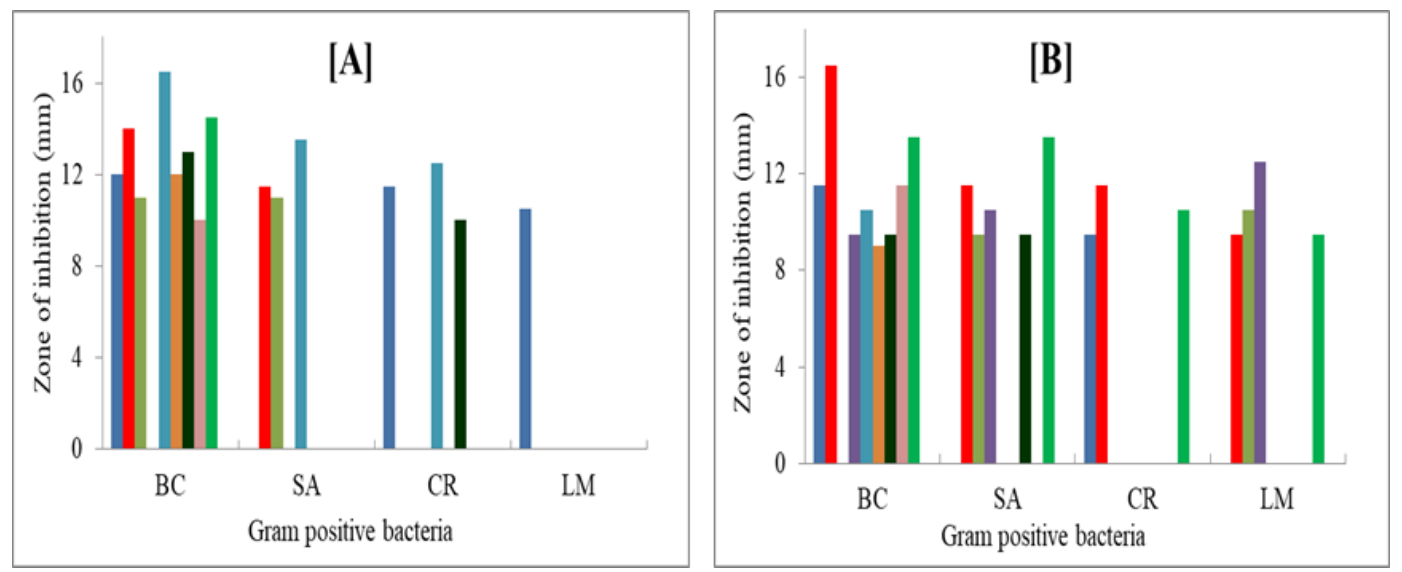

Figure 4 Antimicrobial activity of ITA-1 to ITA-10 against Gram positive bacteria in [A] DMF and [B] DMSO.

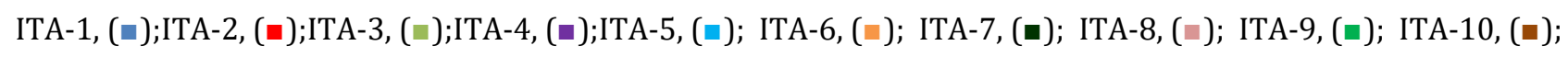

Comparison of inhibition in DMF and DMSO against selected Gram positive bacteria suggest that overall, there is not much effect of solvent on inhibition. Compound ITA-10 containing 4-nitro group is not effective at all in both the solvents.

Figure $5[\mathrm{~A}]$ shows zone of inhibition against Gram negative bacteria in DMF. Against EC, only ITA-4 and ITA-5 containing 3- $\mathrm{NO}_{2}$ and 4-Br substitution respectively exhibited inhibition. The inhibition is higher for ITA-5 as compared to ITA-4.The rest of the compounds had no effect. Only, ITA-3 and ITA-9 having 4-F and 4-OH substitution could inhibit PA. However, the inhibition is more in ITA-9 than ITA-3. The compounds ITA-1, ITA-6, ITA-7 and ITA-8 could not inhibit ST. About half of compounds (ITA-2, ITA-3, ITA-4, ITA-5, ITA-9 and ITA-10) could inhibit ST. ITA-3 and ITA-10 showed maximum inhibition in ST bacteria and ITA-4 showed minimum inhibition. Thus, 4-flouro and 4-nitro groups are more effective against ST as compared to other groups. Against KP, only compounds ITA-4, ITA-5 and ITA-9 showed inhibition and inhibition is maximum for ITA-5 and minimum for ITA-9. Thus, against 4-bromo group is most effective against KP. The compounds ITA-1, ITA-6, ITA-7, ITA-8 and ITA-10 could not inhibit the selected Gram negative bacteria. Thus, in DMF, EC and PA are resistant bacteria whereas ST is the most susceptible bacteria.

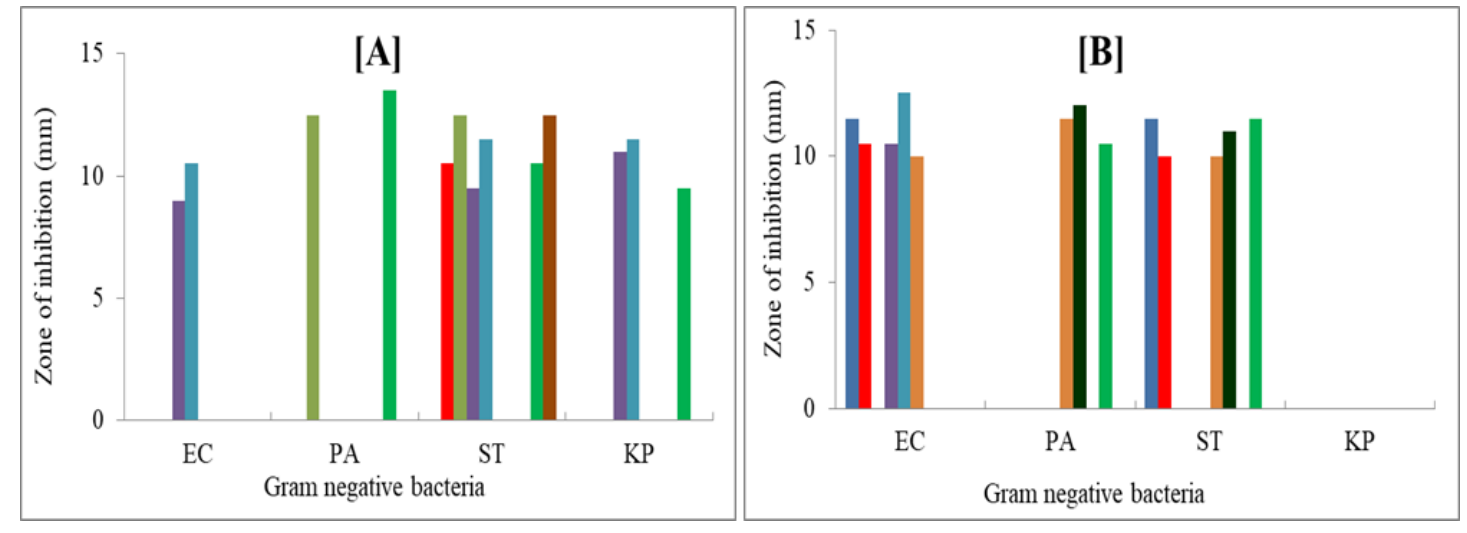

Figure 5 Antimicrobial activity of ITA-1 to ITA-10 against Gram negative bacteria in [A] DMF and [B] DMSO.

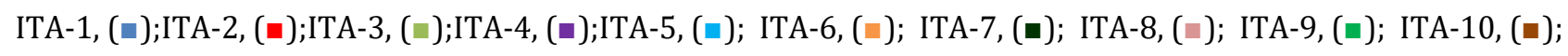

Figure 5 [B] shows inhibition of compounds against Gram negative bacteria in DMSO. Against EC, only half of the compounds exhibited inhibition and maximum is observed for ITA-5 having 4-bromo group. Only ITA-6, ITA-7 and ITA9 could inhibit PA and maximum inhibition is observed for ITA-7 containing 4-methyl group. Against ST, again only half 
of the compounds ITA-1, ITA-2, ITA-6, ITA-7 and ITA-9 showed inhibition. Maximum inhibition is exhibited by ITA-1 and ITA-9 containing 4-chloro and 4-hydroxy groups respectively. Not a single compound could inhibit KP. Thus, KP is the most resistant bacteria in DMSO. Further, it is observed that in DMSO, compounds ITA-3, ITA-8 and ITA-10 were not effective against the selected Gram negative bacteria.

Over all, inhibition is higher in DMF as compared to DMSO. Further, against the studied Gram negative bacteria the compounds ITA- 8 and ITA- 10 are not effective at all in both the solvents.

Figure 6 shows zone of inhibition against some fungal strains in DMF and DMSO. In DMF (Figure 6 [A]), it is observed that only ITA-1 containing 4-chloro group showed inhibition against CG fungal strain. Other compounds had no effect at all. However, against CE, only ITA-5 having 4-Br group is not effective. All other compounds show moderate activity against $\mathrm{CE}$ and maximum is exhibited by ITA-10 having 4-nitro group. For CA, most of the compounds showed inhibition and maximum is observed for ITA-5. Only ITA-6, ITA-7, ITA-9 and ITA-10 could inhibit CN. Thus, 4-methoxy, 4-methyl, 4-hydroxy and 4-nitro groups are effective against CN and maximum effect is observed for ITA-10 containing 4-nitro group. It is observed from Table 1 that ITA-2 and ITA-4 contain 2-hydroxy and 3-nitro groups respectively. However, these compounds showed no inhibition against CN. This suggests that position of group is also important for inhibition. In DMF, CG is the most resistant fungal strain.
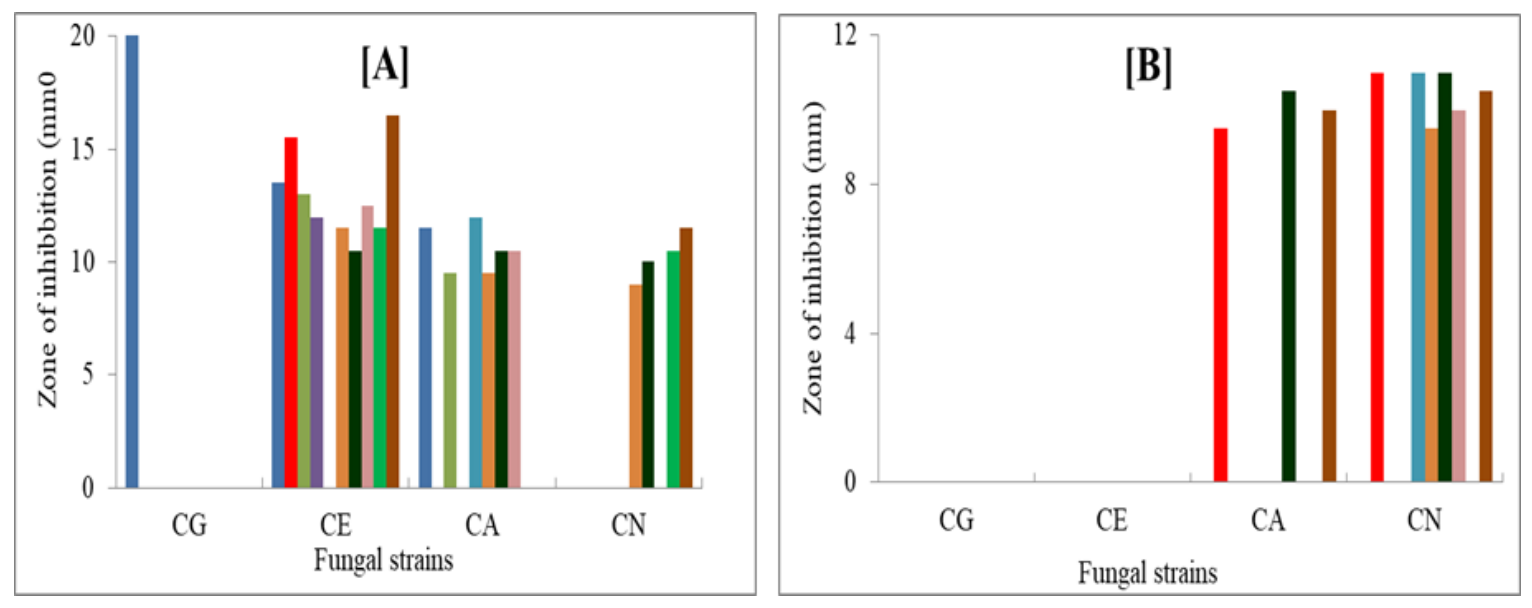

Figure 6 Antifungal activity of ITA-1 to ITA-10 in [A] DMF and [B] DMSO.

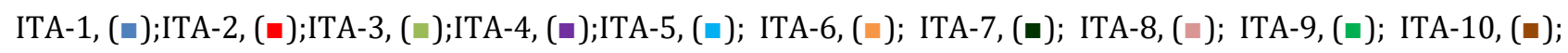

Figure $6[B]$ shows inhibition of compounds against fungal strains in DMSO. Not a single compound could inhibit CG and CE fungal strain. Only three compounds i.e., ITA-2, ITA-7 and ITA-10 could inhibit CA and maximum inhibition is for ITA-7 containing 4-methyl group. For CN strain, ITA-2, ITA-5, ITA-6, ITA-7, ITA-8 and ITA-10 showed inhibition and maximum is for ITA-2, ITA-5 and ITA-7. Thus, 2-hydroxy, 4-bromo and 4-methyl groups are equally effective against this fungal strain. Thus, in DMSO, both CG and CE are resistant bacteria.

Comparison of inhibition in both the solvents suggests that solvent plays an important role in inhibition. Inhibition is higher in DMF than in DMSO. So DMF is good for solvent for the studied compounds in selected fungal strains.

\section{Conclusion}

Over all, the studied compounds show moderate activity against Gram positive bacteria, Gram negative bacterial and fungal strains. Solvent plays an important role and side chain substitutions also affect microbial activity.

\section{Compliance with ethical standards}

\section{Acknowledgments}

Authors are thankful to Head of Chemistry department and Head of Bioscience department for providing necessary facilities. 


\section{Disclosure of conflict of interest}

There is no conflict of interest.

\section{References}

[1] J Wang, Y Song and X Gao. (2008). Synthesis of aminoantipyrinechromones Schiff base in ionic liquid, HechengHuaxue, 16, 225-226.

[2] Q F Cheng, X Y Xu, Q F Wang, B H Qian, W J Liu, X J Yang and J Hua. (2009). Synthesis and crystal structure of 3$\{[(1 \mathrm{E}) 1-(2-h y d r o x y p h e n y l) m e t h y l i d e n e]$ amino $\}$-4- cyanopyrazole, 28, 1281-1285.

[3] A Bongini, M Panunzio, G Piersanti, E Bandini, G Martelli, G Spunta and A Venturini. (2000).Stereochemical aspects of a two-step staudinger reaction-asymmetric synthesis of chiral azetidine-2-ones, Eur. J. Org. Chem., 13, 2379-2390.

[4] G Weber and J Messerschmidt. (2005). Signal enhancement in adsorptive stripping voltammettry of Pt by forced convection during the measurement step, Ana. Chim. Acta, 545, 166-172.

[5] V VMulwad and J M Shirodkar. (2002). Synthesis and biological activity of some new Schiff 's bases, thiazolidinones and azetidinones of 4-hydroxycoumarin, Ind. J. Heterocyl. Chem., 11, 199-202.

[6] R Singh and N K Kaushik. (2007). Studies on organotin(IV) and organozinc(II) complexes with some dithiocarbazate Schiff bases, Main Group. Met. Chem., 30, 333-344.

[7] S Zhu, Z Zhou and B Zhao. (2008). Solid synthesis and studies on thermochromism of double schiff base and its complex of nickel(II), Huaxue Yu ShengwuGongcheng, 25, 34-35.

[8] H V Euler and H Hans. (1953). The Structure and Stability of Schiff bases and their intermediates,Arkiv. Kemi, 6,287-292.

[9] D Roy, SP Babu, NC Sukul, S Garai and BP Das. (1993).Nematicidal effect of Schiff base of 2-aminothiazole and salicylaldehyde, Ind. Bio., 25, 43-45.

[10] Q Yu, R Hu and L Hong. (2001). Synthesis and characterization and bioactivity of molybdenum (VI) complexes with Schiff base, ZiranKexueban, 19, 63-66.

[11] S Kaushal and KK Chahal. (2008). Schiff bases of Khusilal-synthesis and their antifungal activity, Civil Lines Pestology, 32, 47-49.

[12] H S Hothi, AMakkar, J R Sharma and M R Manrao. (2008). Synthesis and antifungal 8 potential of Schiff bases of 2'-hydroxyacetophenone and their $\mathrm{Cu}(\mathrm{II})$ complexes, Ind. J. Agri. Chem., 41, 53-58.

[13] BT Thaker, KR Surati and CK Modi. (2008). Synthesis, spectral, thermal, and antibacterial investigation of mixed ligand complexes of oxo-vanadium (IV), Russ. J. Coord. Chem., 34, 25-33.

[14] ZH Chohan and S Mushtaq. (2000). Antibacterial cobalt (II) and zinc (II) complexes of pyrazine-derived NNO and NNN donor Schiff-bases, Pak. J. Pharma. Sci., 13, 21-27.

[15] Z Yang, R Yang, F Li and K Yu. (2000). Crystal structure and antitumor activity of some rare earth metal complexes with Schiff base, Polyhedron, 19, 2599-2604.

[16] T L Yang and WW Qin. (2006). Transition metal manganese (II), nickel (II), copper (II) and zinc (II) complexes of a new Schiff base ligand: synthesis, characterization and antitumor activity studies, Polish J. Chem., 80, 16571662.

[17] P Vicini, AGeronikaki, M Incerti, BG Busonera, CA Poni, C Cabras, CP La. (2003). Synthesis and biological evaluation of benzo[d]isothiazole, benzothiazole and thiazole Schiff bases, Bioorg. Med. Chem., 11, 4785-4789.

[18] D Sriram, P Yogeeswari and TG Kumar. (2005). Microwave-assisted Synthesis, anti- HIV, and anti-YFV activities of Schiff bases of N-hydroxy-N1-aminoguanidine tosylate, Ind. J. Pharm. Sci., 67, 493-496.

[19] S Bawa and S Kumar. (2009). Synthesis of Schiff's bases of 8-methyl-tetrazolo [1,5-a] quinoline as potential antiinflammatory and antimicrobial agents, Ind. J. Chem., 48, 142-145.

[20] M Bhattacharya, SA Iqbal and S Malik. (2005). Physico-chemical study of furosemide salicylaldehyde Schiff base complexes of Hg (II) and Ag (I) metal ions, Mat. Sci. Res. Ind., 3, 85-88. 
[21] R Bardia, RD Singh and JT Rao. (2005). Synthesis and insecticidal activity of 3-(2-pyrimidyl)-2-arylthiazolidin-4ones, J. Inst. Chem., 77, 144-146.

[22] J Parekh, P Inamdar, R Nair, S Baluja and S Chanda. (2005). Synthesis and antibacterial activity of some Schiff bases derived from 4-amino benzoic acid, J. Serb. Chem. Soc., 70, 1155- 1161.

\section{How to cite this article}

Baluja S, Chanda S, Ganguly S, Oza S and Nandha K. (2019). Synthesis and antimicrobial screening of some Schiff bases. (Coleoptera: Curculionidae) on stored maize. GSC Biological and Pharmaceutical Sciences, 9(3), 99-108. 